\title{
Appraising efficiency of OpSite as coolant in drilling of bone
}

\author{
Mohammad Reza Effatparvar ${ }^{1}$, Nima Jamshidi ${ }^{1 *}$ and Alireza Mosavar ${ }^{2}$
}

\begin{abstract}
Background: During drilling of bone, which is common in clinical surgeries, heat generation increases local temperature in the drilling site. Transmission of excessive heat to the surrounding bone tissue can cause thermal osteonecrosis. Consequently, it may lead to failure of implants and fixation screws or delay in healing process. Using cooling is a method for limiting temperature elevation.

Materials and methods: In this study, through comparing three conditions of drilling without cooling, external cooling with normal saline, and external cooling with OpSite spray, the efficiency of OpSite as coolant is studied. In this regard, 2 drill bit diameters, 3 drilling speeds, and 3 drilling feed-rates are considered as drilling variables in the experiments.

Results: For the whole experiments, while cooling with normal saline resulted in lower maximum temperatures than without cooling condition, OpSite had even better results and limited the temperature elevation during drilling of bone efficiently.

Conclusion: OpSite spray, which has lower infection risks than normal saline on one hand and lower maximum temperature rise with all combinations of drilling parameters on the other hand, can be considered in clinical surgeries for cooling applications.
\end{abstract}

Keywords: Bone drilling, OpSite, Osteonecrosis, Saline, Temperature variation, Cooling

\section{Introduction}

During drilling of bone, which is common in orthopaedic surgeries and prosthodontics [1], plastic deformation of bone chips, friction between the bone and drill bit, and also friction between chips and hole wall cause heat generation in the region $[2,3]$. The generated heat increases temperature and can cause thermal osteonecrosis which is death of bone cells (osteocytes) due to thermal overload [4]. Subsequently, it increases risks of failure of implants or delay in healing process. Hence, there are various studies to decrease and control the heat generation. Evaluating different drilling methods, such as ultrasonic-assisted drilling [2] and water jet

\footnotetext{
* Correspondence: n.jamshidi@eng.ui.ac.ir

'Department of Biomedical Engineering, Faculty of Engineering, University of Isfahan, Isfahan, Iran

Full list of author information is available at the end of the article
}

drilling [5], drilling techniques, like as one step and gradual drilling techniques $[6,7]$, drilling parameters, including drilling speed, force, and feed-rate $[6,8-12]$, tool parameters (geometry) $[8,12-14]$, and cooling conditions, including internal and external cooling methods $[6,8,15-17]$ and various coolants [3] are amongst the main efforts in this regard.

In order to control the heat generation in drilling site, while there were positive results for external irrigation in the literature $[6,8,16,17]$, there is a risk of infection for common cooling fluids (water and normal saline) in orthopedic surgery which restricts their usage [3].

To prevent the risk of infection, the aim of this in vitro study was to investigate the efficiency of external cooling with OpSite spray and to compare it to cooling with normal saline. OpSite is a bio-compatible adherent polyurethane film which is waterproof and permeable to 
water vapor and oxygen [18]. It has clinical applications for providing moist wound environment in superficial wounds and for secondary dressing. According to the aim, various drilling conditions were considered. The experiments were conducted in various combinations of 3 different drilling feed-rates, 3 different drilling speeds, and 2 drill bit diameters.

\section{Materials and methods}

\section{Bone specimens}

For in vitro drilling, bovine Femur diaphysis was bought and employed which is common in orthopaedic animalexperiments with concern to its similar properties to human bone $[13,19]$; however, according to the aim of the study in determining efficiency of the coolant in controlling temperature rise, any possible discrepancy in bone properties does not actually hurt deductions. Fresh bones were prepared according to the literature [20]. Although body blood flow acts as coolant during drilling in vivo, it is negligible based on literature [1].

\section{Experimental parameters}

For drilling, a universal mill was employed and orthopaedic drill bits with 2.7 and $3.5 \mathrm{~mm}$ diameters were used. Moreover, 3 drilling speeds of 500, 1000, and 1500 $\mathrm{rpm}$ and 3 drilling feed-rates of 35,65 , and $85 \mathrm{~mm} / \mathrm{min}$ were considered. In regard to assessing coolant efficiency, three conditions were investigated for every combination of the mentioned drilling parameters, without cooling, external cooling with normal saline, and external cooling with OpSite spray. Furthermore, to ensure the precision and validity of results, the experiments were repeated twice.

\section{Investigation of temperature variations}

In order to record temperature variations during drilling, the temperature is often measured with two methods, either with thermocouples [12, 21] or infrared thermographic camera $[6,14]$. In this study, we used type $\mathrm{K}$ thermocouples. The distance between drilling site and thermocouple site was $0.5 \mathrm{~mm}$ and the depth in which thermocouple was placed in the cortical bone was $3 \mathrm{~mm}$ [8]. Two thermocouples were implemented to measure the temperature variations around each drilling hole (Fig. 1) and average record of them was considered as outcome. In addition, the room temperature was $29{ }^{\circ} \mathrm{C}$ and the bones warmed up to the same temperature.

\section{Results}

Numerical results of the study are presented in Table 1 . In this table, average and tolerance of maximum achieved temperature during each experiment is shown. However, to compare the efficiency of coolants directly, the results are separated for each specific drilling diameter and are also presented in Fig. 2a and Fig. 2b for drilling diameters of 2.7 and $3.5 \mathrm{~mm}$, respectively. In these figures, the combination of each drilling speed and drilling feed-rate is considered as a particular condition in experiments. Thus, the 3 cooling conditions are explicitly compared on the diagrams for each particular combination of the drilling parameters. For example, for drill bit diameter of $3.5 \mathrm{~mm}$, speed of $500 \mathrm{rpm}$, and feed-rate of $35 \mathrm{~mm} / \mathrm{min}$, maximum temperature during experiments for the 3 cooling conditions can be compared on the first column of the diagram in Fig. $2 \mathrm{~b}$.

In regard to statistical analysis, for normality test, the Shapiro-Wilk test was applied. In this test, null hypothesis states that data are taken from normal distributed

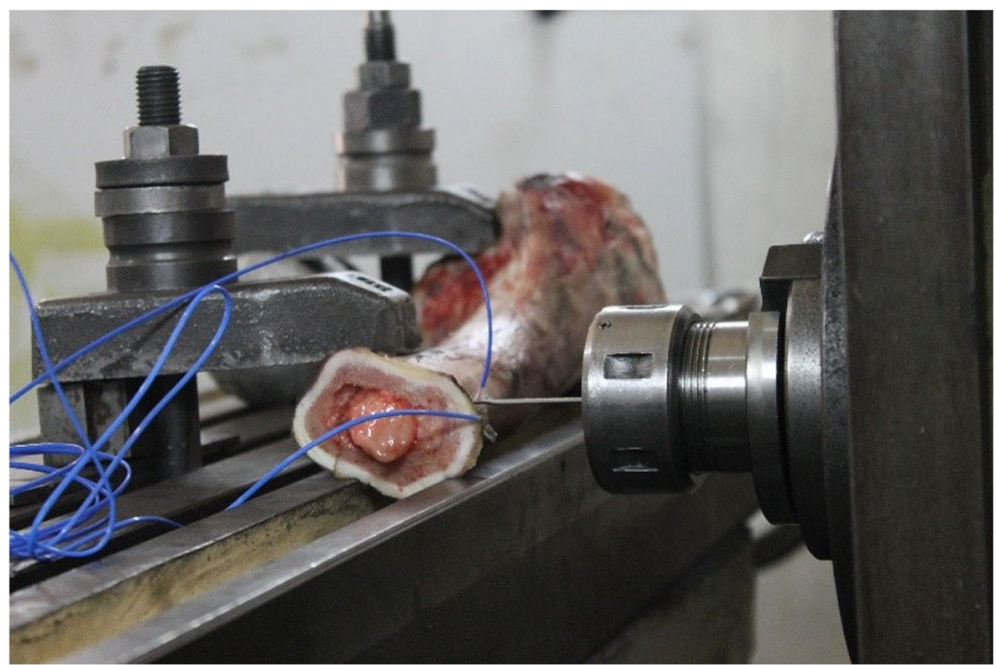

Fig. 1 The setup for drilling and temperature measurement of bovine femoral diaphysis. The employed universal drill had options for regulation of drill speed and feed-rate. Also, the maximum bone temperatures during drilling were measured with two thermocouples 
Table 1 The numerical results of the entire experiments. In the table, the following codes are used. S1: speed of 500 rpm; S2: speed of 1000 rpm; S3: speed of 1500 rpm; F1: feed-rate of $35 \mathrm{~mm} / \mathrm{min}$; F2: feed-rate of $65 \mathrm{~mm} / \mathrm{min}$; F3: feed-rate of $85 \mathrm{~mm} / \mathrm{min}$. Therefore, for example, S1-F2 means drilling with speed of $500 \mathrm{rpm}$ and feed-rate of $65 \mathrm{~mm} / \mathrm{min}$

\begin{tabular}{|c|c|c|c|c|c|c|c|c|c|c|}
\hline \multirow{3}{*}{$\begin{array}{l}\text { Drilling } \\
\text { diameter }\end{array}$} & \multirow{3}{*}{$\begin{array}{l}\text { Coolant } \\
\text { type }\end{array}$} & \multicolumn{9}{|c|}{ Drilling speed and feed-rate } \\
\hline & & $\mathrm{S1-F1}$ & S1-F2 & S1-F3 & S2-F1 & S2-F2 & S2-F3 & S3-F1 & S3-F2 & S3-F3 \\
\hline & & \multicolumn{9}{|c|}{ Maximum temperature of experiment $\left({ }^{\circ} \mathrm{C}\right)$} \\
\hline \multirow[t]{3}{*}{$2.7 \mathrm{~mm}$} & None & $36.0 \pm 3$ & $36.0 \pm 2$ & $39.0 \pm 2$ & $28.9 \pm 2$ & $39.0 \pm 3$ & $74.0 \pm 1$ & $53.0 \pm 2$ & $35.2 \pm 3$ & $62.0 \pm 1$ \\
\hline & Saline & $35.7 \pm 2$ & $32.0 \pm 1$ & $36.0 \pm 3$ & $28.0 \pm 1$ & $27.0 \pm 4$ & $44.8 \pm 2$ & $33.0 \pm 3$ & $29.0 \pm 2$ & $30.0 \pm 1$ \\
\hline & OpSite & $27.0 \pm 2$ & $25.1 \pm 3$ & $33.0 \pm 2$ & $25.1 \pm 2$ & $25.0 \pm 3$ & $35.2 \pm 1$ & $22.0 \pm 2$ & $22.0 \pm 3$ & $21.4 \pm 1$ \\
\hline \multirow[t]{3}{*}{$3.5 \mathrm{~mm}$} & None & $36.0 \pm 2$ & $36.0 \pm 3$ & $38.0 \pm 1$ & $45.7 \pm 2$ & $43.7 \pm 2$ & $65.5 \pm 1$ & $66.0 \pm 1$ & $42.3 \pm 3$ & $41.0 \pm 3$ \\
\hline & Saline & $26.0 \pm 1$ & $34.7 \pm 2$ & $27.9 \pm 1$ & $37.2 \pm 2$ & $38.9 \pm 1$ & $31.0 \pm 2$ & $49.7 \pm 3$ & $36.2 \pm 1$ & $38.4 \pm 3$ \\
\hline & OpSite & $24.0 \pm 2$ & $30.0 \pm 1$ & $25.7 \pm 3$ & $34.0 \pm 2$ & $37.0 \pm 3$ & $29.1 \pm 2$ & $31.6 \pm 3$ & $30.0 \pm 1$ & $26.5 \pm 2$ \\
\hline
\end{tabular}

\section{a}

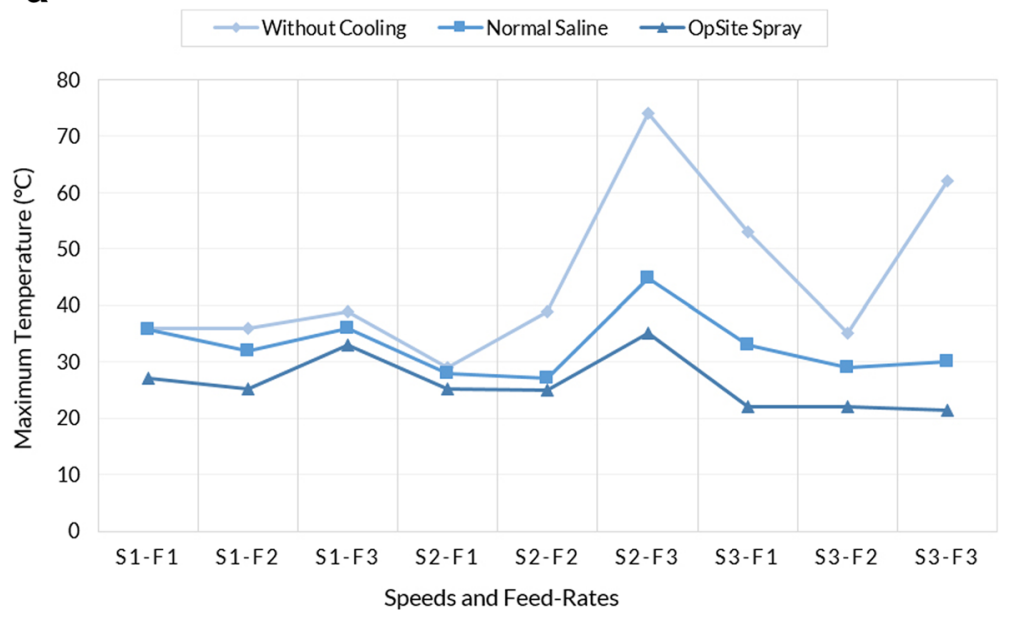

b

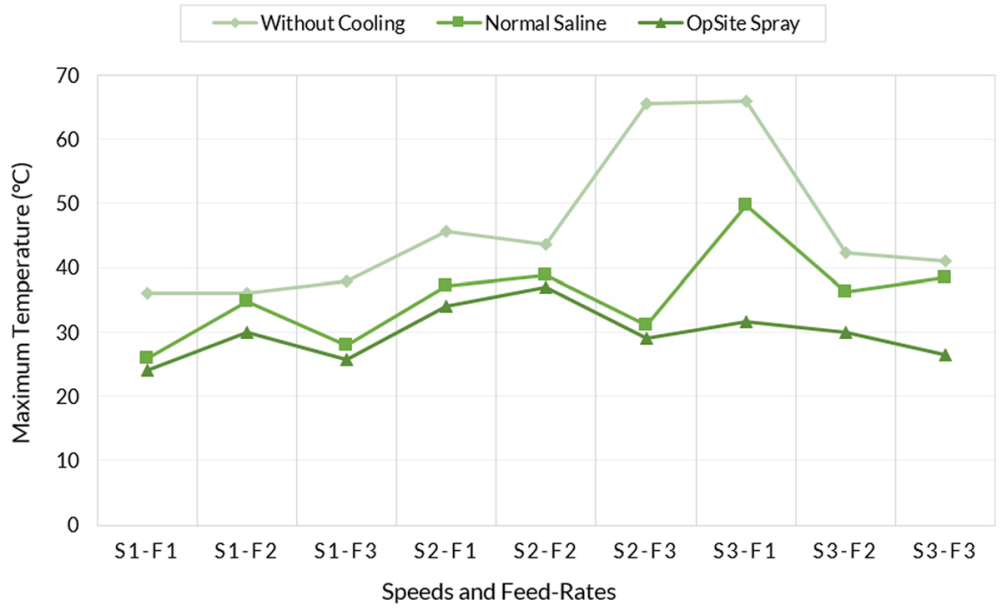

Fig. 2 Diagrams of maximum recorded temperature in experiments with a drill bit diameter of $2.7 \mathrm{~mm}$, and $\mathbf{b}$ drill bit diameter of $3.5 \mathrm{~mm}$. In the diagrams the following codes are used. S1: speed of 500 rpm; S2: speed of 1000 rpm; S3: speed of 1500 rpm; F1: feed-rate of 35 mm/min; F2: feed-rate of $65 \mathrm{~mm} / \mathrm{min}$; F3: feed-rate of $85 \mathrm{~mm} / \mathrm{min}$. Therefore, for example, first columns show the results for drilling with speed of $500 \mathrm{rpm}$ and feed-rate of $35 \mathrm{~mm} / \mathrm{min}$ 
population. So, when $P>0.05$, null hypothesis is accepted and data are called as normally distributed. According to this test, our results showed normal distribution for each group of $2.7 \mathrm{~mm}$ and $3.5 \mathrm{~mm}$ diameters. As a further step, the one-way analysis of variance (ANOVA) was used to determine whether there were any statistically significant differences between the means of the three independent groups. The results regarding the difference between the three cooling methods had $P$ value of $<0.05$ which indicates the differences are significant. Since ANOVA test only reveals differences between groups and does not examine each group separately, Dunnett T3 test was used to examine group by group. The results of this test also showed the significant differences about using of OpSite spray against normal saline and without cooling condition (Table 2).

\section{Discussion}

There are a variety of studies on investigating the effect of external cooling during drilling of bone and all of them emphasize its positive influence in limiting the maximum temperature elevation [22]. Augustin et al. [8] investigated the effect of external irrigation with water as coolant. They indicated that while there are several parameters that increase bone temperature during drilling, cooling (as external irrigation in their case) can be the only and the most important factor in limiting this increase in bone temperature and must be used for bone drilling. On the other hand, Shakouri et al. [3], Sener et al. [17], Al-Dabag and Sultan [23], and Sindel et al. [24] determined the efficiency of external cooling with normal saline as coolant. They also indicated similar positive influence in limiting the maximum temperature elevation. Therefore, the lower maximum temperatures, which are seen in Fig. 2a, b for external cooling with normal saline in comparison to the condition that there was no cooling, are not a surprise; the results thoroughly support the previous studies on external cooling.

Moreover, studies on the effect of drilling speed and feed-rate on temperature elevation are not consistent [22].

Table 2 The results of statistical analyses for the entire experiments.

\begin{tabular}{llll}
\hline Statistical tests & $\begin{array}{l}\text { Coolant } \\
\text { type }\end{array}$ & \multicolumn{2}{l}{ Drilling diameter } \\
\cline { 3 - 4 } & & $\begin{array}{l}2.7 \mathrm{~mm} \\
P \text { value }\end{array}$ & $3.5 \mathrm{~mm}$ \\
\hline Shapiro-Wilk & None & 0.07 & 0.311 \\
& Saline & 0.20 & 0.848 \\
One-Way ANOVA & OpSite & 0.07 & 0.913 \\
Dunnett T3 & All & 0.000 & 0.004 \\
& None & 0.052 & 0.052 \\
& Saline & 0.000 & 0.000 \\
& OpSite & 0.045 & 0.045 \\
\hline
\end{tabular}

This was also the case when external cooling was employed since in the experiments of Shakouri et al. [3], there is no trend for temperature variations with changes in drilling speed, neither without cooling nor with external cooling. In spite of this, the external cooling efficiency in limiting the temperature rise is observed with all combinations of parameters in the current study.

According to Table 1 and Fig. 2, using OpSite spray not only limited the maximum temperature elevation in our experiments, but also shows much better results in comparison to normal saline. It is more important if consider the lower risks of infection for this coolant since it is not liquid but rather is in the form of spray [3]. Furthermore, according to the literature, for occurrence of thermal osteonecrosis, there is a reverse exponential relationship between thermal necrosis temperature and necrosis time. Whereas the exact threshold temperature for thermal osteonecrosis in human bone is unknown, heat transfer to the bone cells in an average temperature of $47^{\circ} \mathrm{C}$ for $1 \mathrm{~min}$ is believed to be the threshold [22]. However, OpSite successfully limited the temperature elevation and the highest recorded temperature for cooling with OpSite spray was $37{ }^{\circ} \mathrm{C}$. Thus, the risks of thermal osteonecrosis during drilling and consequent risks of loosening and failure in the implants and orthopedic fixation screws are much lower when using OpSite as coolant.

With regard to the results of this study, it can be concluded that though employment of a cooling system has positive effects in controlling temperature rise during drilling of bone, using OpSite spray as coolant for external cooling is recommended in orthopaedic surgeries due to lower risks of thermal osteonecrosis (better subsequent osseointegration and thus more success rate) and infection.

However, more in vivo studies on its clinical success are needed, both on animals and human. Moreover, to have a better conclusion, further osteonecrosis evaluations on histopathology of the surrounding tissue may be helpful.

\section{Conclusion}

In this study, use of OpSite as coolant in bone drilling was proposed, thus, for three conditions, without cooling, external cooling with normal saline, and external cooling with OpSite spray, the efficiency of OpSite as coolant was studied. In this regard, entire combinations of some drilling parameters, including drill bit diameter, drilling speed, and drilling feed-rate were considered. For the whole experiments, while cooling with normal saline resulted in lower maximum temperatures than without cooling condition, OpSite had even better results and limited the temperature elevation during drilling of bone efficiently. Therefore, due to its lower risks for infection and thermal osteonecrosis in comparison to normal saline, it can be recommended for clinical surgeries in cooling applications. 


\section{Acknowledgements}

The authors declared no acknowledgements related to this study.

\section{Authors' contributions}

Conception or design of the work by MRE and NJ; acquisition, analysis, and interpretation of data for the work by all authors; drafting the work by AM and NJ; and revising it critically by all authors. All authors read and approved the final manuscript

\section{Funding}

There was not funding available for this study.

\section{Availability of data and materials}

All data generated or analyzed during this study are included in this published article.

\section{Ethics approval and consent to participate}

Not applicable.

\section{Consent for publication}

Not applicable.

\section{Competing interests}

The authors declare that they have no competing interests.

\section{Author details}

'Department of Biomedical Engineering, Faculty of Engineering, University of Isfahan, Isfahan, Iran. ${ }^{2}$ School of Mechanical Engineering, College of Engineering, University of Tehran, Tehran, Iran.

Received: 10 January 2020 Accepted: 13 May 2020

Published online: 29 May 2020

\section{References}

1. Augustin G, Zigman T, Davila S, Udillijak T, Staroveski T, Brezak D, Babic S. Cortical Bone Drilling and Thermal Osteonecrosis. Clinical Biomechanics. 2012;27:313-25

2. Denis K, van Ham G, Vander Sloten J, van Audekercke R, van der Perre G, De Schutter J, Kruth JP, Bellemans J, Fabry G. Influence of Bone Milling Parameters on the Temperature Rise, Milling Forces and Surface Flatness in View of Robot-Assisted Total Knee Arthroplasty. International Congress Series. 2001:1230:300-6.

3. Shakouri E, Haghighi Hassanalideh H, Gholampour S. Experimental Investigation of Temperature Rise in Bone Drilling with Cooling: A Comparison between Modes of without Cooling, Internal Gas Cooling, and External Liquid Cooling. Proceedings of the Institution of Mechanical Engineers, Part H. 2018;232:45-53.

4. Eriksson AR, Albrektsson T, Albrektsson B. Heat Caused by Drilling Cortical Bone: Temperature Measured in vivo in Patients and Animals. Acta Orthopaedica Scandinavica. 1984;55:629-31.

5. den Dunnen S, Kraaij G, Biskup C, Kerkhoffs GMMJ, Tuijthof GJM. Pure Waterjet Drilling of Articular Bone: An in vitro Feasibility Study. Strojniski Vestnik - Journal of Mechanical Engineering. 2013:59:425-32.

6. Kalidindi V (2004) Optimization of Drill Design and Coolant Systems during Dental Implant Surgery. PhD thesis, University of Kentucky, USA

7. Möhlhenrich SC, Abouridouane M, Heussen N, Hölzle F, Klocke F, Modabber A. Thermal Evaluation by Infrared Measurement of implant site preparation between Single and Gradual Drilling in Artificial Bone Blocks of Different Densities. International Journal of Oral and Maxillofacial Surgery. 2016;45: 1478-84.

8. Augustin G, Davila S, Mihoci K, Udiljak T, Vedrina SD, Antabak A. Thermal Osteonecrosis and Bone Drilling Parameters Revisited. Archives of Orthopaedic and Trauma Surgery. 2008;128:71-7.

9. Bachus KN, Rondina MT, Hutchinson DT. The Effects of Drilling Force on Cortical Temperatures and Their Duration: An in vitro Study. Medical Engineering and Physics. 2000:22:685-91.

10. Davidson SRH, James DF. Drilling in Bone: Modeling Heat Generation and Temperature Distribution. Journal of Biomechanical Engineering. 2003;1253: 305-14.
11. Bertollo N, Walsh WR (2011) Drilling of Bone: Practicality, Limitations and Complications Associated with Surgical Drill-Bits. Biomechanics in Applications: $53-83$

12. Karaca F, Aksakal B, Köm M. Influence of Orthopaedic Drilling Parameters on Temperature and Histopathology of Bovine Tibia: An in vitro Study. Medical Engineering and Physics. 2011;33:1221-7.

13. Hillery MT, Shuaib I. Temperature Effects in the Drilling of Human and Bovine Bone. Journal of Materials Processing Technology. 1999:92:302-8.

14. Udiljak T, Ciglar D, Skoric S. Investigation into Bone Drilling and Thermal Bone Necrosis. Advances in Production Engineering and Management. 2007;2:103-12.

15. Benington IC, Biagioni PA, Briggs J, Shearidan S, Lamey PJ. Thermal changes observed at implant sites during internal and external irrigation. Clinical Ora Implants Research. 2002;13:293-7.

16. Bagci E, Ozcelik B. Effects of Different Cooling Conditions on Twist Drill Temperature. International Journal of Advanced Manufacturing Technology. 2007:3:867-77.

17. Sener BC, Dergin G, Gursoy B, Kelesoglu E, Slih I. Effects of Irrigation on Heat Control in vitro at Different Drilling Depths. Clinical Oral Implants Research. 2009:20:294-8.

18. Foster AV1, Eaton C, McConville DO, Edmonds ME (1994) Application of OpSite Film: A New and Effective Treatment of Painful Diabetic Neuropathy. Diabetic Medicine. 11: 768-772.

19. Shakouri E, Sadeghi MH, Maerefat M, Shajari S. Experimental and Analytical Investigation of the Thermal Necrosis in High-Speed Drilling of Bone. Proceedings of the Institution of Mechanical Engineers, Part H. 2014;228: 330-41.

20. Wang W, Shi Y, Yang N, Yuan X. Experimental Analysis of Drilling Process in Cortical Bone. Medical Engineering and Physics. 2014;36:261-6.

21. Sezek S, Aksakal B, Karaca F. Influence of drill parameters on bone temperature and necrosis: a FEM modelling and in vitro experiments. Computational Materials Science. 2012;60:13-8.

22. Pandey RK, Panda SS. Drilling of bone: a comprehensive review. Journal of Clinical Orthopaedics and Trauma. 2013:4:15-30.

23. Al-Dabag AN, Sultan AA. Effect of cooling an irrigation solution during preparation of implant site on heat generation using elite system for implant (experimental study). Al-Rafidain Dental Journal. 2010;10:260-4.

24. Sindel A, Dereci Ö, Hatipoğlu M, Altay MA, Özalp Ö, Öztürk A. The effects of irrigation volume to the heat generation during implant surgery. Medicina Oral Patologia Oral y Cirugia Bucal. 2017;22:e506-11.

\section{Publisher's Note}

Springer Nature remains neutral with regard to jurisdictional claims in published maps and institutional affiliations.

Ready to submit your research? Choose BMC and benefit from:

- fast, convenient online submission

- thorough peer review by experienced researchers in your field

- rapid publication on acceptance

- support for research data, including large and complex data types

- gold Open Access which fosters wider collaboration and increased citations

- maximum visibility for your research: over $100 \mathrm{M}$ website views per year

At BMC, research is always in progress.

Learn more biomedcentral.com/submission 